\title{
Evaluation of canine and feline leishmaniasis by the association of blood culture, immunofluorescent antibody test and polymerase chain reaction
}

\author{
Audrey Rennó Campos Braga', Hélio Langoni ${ }^{2}$ and Simone Baldini Lucheis $3^{3^{*}}$
}

\begin{abstract}
Background: This study aimed to evaluate the occurrence of Leishmania spp. in dogs and cats from Botucatu, São Paulo state, and Campo Grande, Mato Grosso do Sul state, Brazil, by the association of three diagnostic tests: blood culture in liver infusion tryptose medium, immunofluorescent antibody test and polymerase chain reaction. Fifty blood samples of dogs and cats from the Center for Zoonosis Control in Campo Grande, an area endemic for canine visceral leishmaniasis, were collected randomly, as well as canine and feline blood samples from the Municipal Kennel and Animal Protection Association in Botucatu, currently considered a transmission-free, non-endemic area.
\end{abstract}

Results: Of the 50 dog blood cultures from Botucatu, three (6\%) were positive and of the 50 cats, two (4\%) were positive. In Campo Grande, 29 dog blood cultures (58\%) were positive and all (100\%) cats negative by this test. Polymerase chain reaction detected Leishmania spp. in 100\% of dog and cat samples from Botucatu but found all the cats from Campo Grande to be negative. On the other hand, 36 dogs from Campo Grande were positive (72\%) by the same technique. Immunofluorescent antibody test in Botucatu found $100 \%$ of dogs and cats non-reactive, while in Campo Grande, it detected positivity in 32 dogs (64\%) and 15 cats (30\%).

Conclusions: The results show the importance of not only continuous epidemiological surveillance in areas not endemic for leishmaniasis, but also research for accurate diagnosis of this zoonosis.

Keywords: Dog, Cat, Diagnosis, Leishmaniasis, Zoonosis

\section{Background}

Leishmania infantum (syn. L. chagasi) is the causative agent of visceral leishmaniasis (VL) in the New World, with endemic areas ranging from the southern USA to northern Argentina [1]. It is considered an important but neglected disease that affects many countries and, in recent years, has become an important public health problem, transmitted to humans through stings of phlebotomine sand flies Lutzomyia longipalpis. Brazil is a country with a high number of cases ( 90\%) [2].

\footnotetext{
*Correspondence: silucheis@apta.sp.gov.br

${ }^{3}$ Agência Paulista de Tecnologia dos Agronegócios (APTA/SAA), Polo Regional Centro-Oeste, Av. Rodrigues Alves, 40-40, Bauru SP CEP 17030-000, Brazil

Full list of author information is available at the end of the article
}

Some behavioral features of cats, such as nocturnal predatory hunting, walking as far as $1.5 \mathrm{~km}$ from their homes, and cohabitating in wild and domestic areas, favor the dissemination of the parasite to this species [3].

The frequent failures to diagnose feline leishmaniasis (FL) are attributable not only to the widespread unawareness of the disease by health professionals including veterinarians, along with the diminished frequency of cats in veterinary clinics, but also to the scarcity of studies about the epidemiological and clinical-pathological aspects of the disease. This context has hampered understanding of the true role of cats as reservoirs of Leishmania spp. and their importance in public health [4-7].

The greatest difficulty found is posed by the diagnosis of canine visceral leishmaniasis (CVL), since the 
methods utilized to its control are based on antibody research, which has its limitations. Thus, the identification of infected dogs is the key point to interrupt the epidemiologic chain of the disease in urban areas.

Serological diagnosis of CVL previously recommended by the Program of Surveillance and Control of Leishmaniasis was comprised of ELISA as the screening method and immunofluorescent antibody test (IFAT) as confirmatory [8]. In order to improve the diagnostic technique of $\mathrm{CVL}$, the Ministry of Health has established the replacement of the currently used protocol (screening with ELISA and confirmation with IFAT), with the deployment of rapid immunoassay with recombinant antigens (k26 and k39) as screening and ELISA as confirmatory [9].

The isolation of promastigote forms of Leishmania spp. by means of culturing any of several tissues, such as blood in the case of blood cultures, though laborious, is also a possible technique [10].

Among molecular methods, the polymerase chain reaction (PCR) has been used as a tool in epidemiological research studies to identify species of Leishmania spp. by selective amplification of DNA sequences of the parasite. The DNA detection is possible in a variety of tissues, including bone marrow, skin biopsies, lymph node aspirates, blood, histological sections of paraffin-embedded tissues and also in the vector [10,11].

For better diagnostic acuity of VL, it is necessary to employ a combination of techniques since there is no method that singly gathers all desirable features for the diagnosis, such as: easy execution, accessible cost, rapidity and especially high sensitivity and specificity. It is recommended that this disease be diagnosed based on clinical symptomatology, on the epidemiological features of the region and on laboratorial exams, thereby contributing to the correct treatment of truly positive animals. The present work aimed to verify the occurrence of Leishmania spp. in dogs and cats from an area endemic for leishmaniasis (Campo Grande, Mato Grosso do Sul state) and another nonendemic area (Botucatu, São Paulo state). For both, we used the association of thee diagnostic methods: blood culturing, IFAT and the PCR from the blood cultures of these animals.

\section{Methods}

Animals

Two hundred animals were studied, one hundred from Botucatu (fifty dogs and fifty cats) and one hundred from Campo Grande (fifty dogs and fifty cats). The analysis performed was EpiInfo.

\section{Blood cultures}

The blood samples were collected randomly in Campo Grande, MS, at the Center for Zoonosis Control (CZC) and in Botucatu, SP, at the Municipal Kennel and Animal
Protection Association (APA). A blood volume from $5 \mathrm{~mL}$ to $8 \mathrm{~mL}$ was collected from each animal, through jugular vein puncture, into tubes with EDTA, and kept refrigerated until their arrival at the laboratory, where they were immediately processed for blood culturing.

\section{Processing sites and reading from blood cultures}

The blood samples of animals from Botucatu, SP, were processed at the Laboratory of Animal Health of the São Paulo Agency of Agribusiness Technology (APTA/SAA), Bauru, SP, whereas those from Campo Grande, MS, were processed at the School of Medicine and Animal Husbandry of the Federal University of Mato Grosso do Sul (UFMS) in the same city. The readings were monitored at the Laboratory of Animal Health of APTA/SAA.

\section{Blood culture in liver infusion tryptose (LIT)}

The culture medium used for the blood samples was LIT. These blood samples were manipulated in a laminar flow cabinet, previously cleaned with $70 \%$ alcohol and kept under ultraviolet light for 20 minutes. For each collected blood sample, the plasmatic and leukocyte portion and the sediment of the erythrocytes were inoculated respectively in three sterile threaded tubes containing $5 \mathrm{~mL}$ of sterile LIT medium each. Then the cultures were incubated and maintained under a temperature of 28 to $30^{\circ} \mathrm{C}$, until four months after inoculation, when they were submitted to PCR for Leishmania spp.

\section{Reading of the blood cultures}

After ten days of the samples inoculation, the cultures were observed every 15 days, for four months, using optical microscopy with $1000 \times$ magnification. Both positive and negative cultures were immediately processed for extraction of the parasitic DNA, after the readings were concluded.

\section{Preparation of blood samples in LIT for the extraction of parasitic DNA}

The positive and negative cultures were washed separately in sterile buffered saline (PBS), $0.01 \mathrm{M}(\mathrm{pH} 7.2)$ and centrifuged at $1000 \mathrm{rpm}$ for ten minutes and the sediment stored in sterile DNAse- and RNAse-free microtubes at $-20^{\circ} \mathrm{C}$, until the moment of extraction of the parasitic DNA [12].

\section{DNA extraction}

The DNA was extracted from $300 \mu \mathrm{L}$ of the stored sediment, subjected to an application of Illustra ${ }^{\text {Tx }}$ blood genomic Prep Mini Spin Kit (GE Healthcare ${ }^{\circ}$ ), and then stored in sterile DNAse- and RNAse-free microtubes and kept at $-20^{\circ} \mathrm{C}$. 
Polymerase chain reaction (PCR)

The primers LINR4 (5' GGGGTTGGTGTAAAATAG GG 3') and LIN19 (5' CAGAACGCCCCTACCCG 3') were used as described by Ikonomopoulos et al. [13]. All the reactions were performed in duplicate, with $2.5 \mu \mathrm{L}$ of PCR buffer ( $50 \mathrm{mmol} \mathrm{KCl,} 10 \mathrm{mmol}$ of Tris- $\mathrm{HCl}, 1.5 \mathrm{mM}$ $\mathrm{MgCl}_{2}$ ), $0.2 \mathrm{mM}$ of deoxynucleotide triphosphate, $1.0 \mathrm{U}$ of Taq Polymerase, 10 pmol of each initiator, $2 \mu \mathrm{L}$ of DNA and $17.8 \mu \mathrm{L}$ of ultrapure water to compose a final volume of $25 \mu \mathrm{L}$.

The amplification steps were carried out in a thermal cycler (MasterCycler Personal, Eppendorf, Germany) according to Ikonomopoulos et al. [13], as follows: initial denaturation in a cycle at $95^{\circ} \mathrm{C}$ for three minutes, followed by 33 cycles at $95^{\circ} \mathrm{C}$ for 30 seconds, $58^{\circ} \mathrm{C}$ for 30 seconds and $72^{\circ} \mathrm{C}$ for one minute and a final extension of $72^{\circ} \mathrm{C}$ for seven minutes.

The amplified products were identified by means of gel electrophoresis in $1.5 \%$ agarose prepared in Tris-boratoEDTA (TBE) buffer $1.0 \mathrm{X}$ and stained with ethidium bromide. The size of the amplified products was compared with the 100 bp ladder and visualized through Gel Doc - It $^{\text {tw }}$ Imaging System, using VisionWorks ${ }^{\circ}$ LS Software (UVP, USA).

\section{Immunofluorescent antibody test (IFAT)}

The IFAT for Leishmania spp. was performed according to Camargo [14].

\section{Ethics statement}

This study was approved by the Ethics Committee on Animal Experimentation of the School of Veterinary Medicine and Animal Husbandry, São Paulo State
University (UNESP), Botucatu, SP, Brazil under protocol number 65/2007.

\section{Statistical analysis}

The diagnostic techniques in this study were evaluated through the estimation of accuracy, sensitivity, specificity, negative predictive value, positive predictive value and kappa coefficient for concordance among the diagnoses of the tests, using PCR as the gold standard. Chisquare test and Fischer's exact test were performed to estimate the association between clinical signs and the positivity for Leishmania spp. [15].

\section{Results and discussion}

\section{Blood culture, IFAT and PCR for Leishmania spp}

Of the analyzed canine blood cultures from Botucatu, three $(6 \%)$ were positive and forty-seven (94\%) negative. But among cats, two samples (4\%) were positive and 48 (96\%) negative. Both the IFAT and PCR for Leishmania spp. found that $100 \%$ of both the dog and cat samples were negative. The blood cultures of animals from Campo Grande presented 29 (58\%) dog samples positive and 21 (42\%) negative. All $(100 \%)$ of the feline samples were negative by blood culture as well by PCR for Leishmania spp. As for the dogs, 36 (72\%) samples were positive and 14 (28\%) were negative by PCR for Leishmania spp. By IFAT, 32 (64\%) dogs were positive and 18 (36\%) negative. Fifteen cats $(30 \%)$ presented positivity by IFAT for Leishmania spp. whereas 35 (70\%) were negative (Table 1). The serum titers varied from 80 to 640 in dogs and 40 to 320 in cats.

Blood cultures are considered positive when, through an optical microscope, it is possible to see the presence of flagellate parasites, which, kept in LIT, can be characterized

Table 1 Estimated percentage of animals with diagnosis for Leishmania spp. by location and species

\begin{tabular}{|c|c|c|c|c|}
\hline Exam & Local & Species & $\%$ relative $^{a}$ & $\mathrm{Cl}(95 \% ; \% \text { relative })^{\mathrm{b}}$ \\
\hline \multirow[t]{4}{*}{$\overline{P C R}$} & Botucatu, SP & Dog & $0.0 \%$ & $-{ }^{c}$ \\
\hline & & Cat & $0.0 \%$ & $-{ }^{c}$ \\
\hline & Campo Grande, MS & Dog & $72.0 \%$ & (59.0-84.0\%) \\
\hline & & Cat & $0.0 \%$ & $-{ }^{c}$ \\
\hline \multirow[t]{4}{*}{ Blood culture } & Botucatu, SP & Dog & $6.0 \%$ & $(0.0-12.7 \%)$ \\
\hline & & Cat & $4.0 \%$ & $(0.0-9.5 \%)$ \\
\hline & Campo Grande, MS & Dog & $58.0 \%$ & (44.0-71.9\%) \\
\hline & & Cat & $0.0 \%$ & $-^{c}$ \\
\hline \multirow[t]{4}{*}{ IFAT } & Botucatu, SP & Dog & $0.0 \%$ & $-{ }^{c}$ \\
\hline & & Cat & $0.0 \%$ & $-{ }^{c}$ \\
\hline & Campo Grande, MS & Dog & $64.0 \%$ & (50.4-77.5\%) \\
\hline & & Cat & $30.0 \%$ & $(17.0-42.9 \%)$ \\
\hline
\end{tabular}

\footnotetext{
an a total of fifty animals, examined by species and location.

${ }^{\mathrm{b} C o n s i d e r i n g}$ the standard error of the proportion estimator associated with the sampling plan.

"Simple random sample with replacement" and unknown population variance.

Impossible to estimate due to null sample variability.
} 
through biochemical and/or molecular biology techniques [16]. Because of its high specificity, this technique makes the positive cultures present a high value, which is important for the isolation and identification of the parasite $[11,17]$.

Out of 50 blood cultures of dogs from Campo Grande, 29 (58.0\%) were positive, but the actual presence of Leishmania spp. parasites was confirmed by means of PCR in 25 (86.2\%), revealing a blood culture sensitivity of $69.4 \%$ (Table 2). The flagellate forms seen in four samples were negative by PCR, as well as three positive dog cultures and two positive cat cultures from Botucatu. These positive samples were $100 \%$ negative by IFAT and PCR tests, suggesting that the parasites seen in the first culture were other trypanosomatids. However, there was no confirmation by PCR, because it was not the aim of this study.

The suspicion above is due to the phylogenetic proximity between these parasites that belong to the same family (Trypanosomatidae), because, despite several studies demonstrating the same cross-reaction by serological methods, the morphological presentation is highly similar in culture.

Of the 21 negative blood cultures of these dogs, ten (47.6\%) presented negative results equivalent to those obtained by PCR, while the blood culture technique presented $71.4 \%$ specificity (Table 2$)$. Similarly, eight (38.0\%) serum samples from these animals presented negative IFAT. Given this context, we suggest the absence of the parasite. The two remaining samples displayed high IFAT titers, both with values of at least 640 , indicating that the dogs may have been infected. The finding may be attributable to the low parasite load at the moment of collection.

Eleven dogs (22.0\%) from Campo Grande were found negative by blood culturing, but positive by PCR for Leishmania spp., due to the low sensitivity of the former, which can present negative or non-conclusive results, especially when the parasitaemia is sufficiently low to hamper observation of the parasites through an optical microscope.

The Campo Grande feline samples presented 100\% negativity in both blood cultures and PCR, whereas the IFAT titers varied from 40 to 320 . In this case, a judicious analysis must be made, because it is believed that

Table 2 Blood cultures and IFAT according to PCR for Leishmania spp

\begin{tabular}{ccccc}
\hline & & \multicolumn{2}{c}{ Blood culture/IFAT } & Total \\
\cline { 3 - 4 } & & Positive & Negative & \\
\hline PCR & Positive & $25 / 29$ & $11 / 7$ & $\mathbf{3 6 / 3 6}$ \\
& Negative & $4 / 3$ & $10 / 11$ & $\mathbf{1 4 / 1 4}$ \\
& Total & $\mathbf{2 9 / 3 2}$ & $\mathbf{2 1 / 1 8}$ & $\mathbf{5 0 / 5 0}$ \\
\hline
\end{tabular}

IFAT immunofluorescent antibody test, $P C R$ polymerase chain reaction. the disease in this species has been misdiagnosed, besides the possibility of cross-reactions with other trypanosomes $[4,18]$.

The seroprevalence for leishmaniasis in the 50 dogs evaluated at the CZC in Campo Grande was 64\% (32/50), with antibody titers that vary from 80 to equal or superior to 640 , considered high when compared to the prevalence indices from epidemiological surveys performed in other Brazilian endemic areas. It is quite important to highlight that, although the canine samples in the present work were collected randomly at the Center for Zoonosis Control in Campo Grande, the prevalence of euthanized dogs in endemic areas is higher than the actual prevalence in the canine population as a whole, because most animals sent to these centers that present clinical suspicion for VL are sick or have already been serologically identified in mass surveys.

Albuquerque et al. [19] also verified seropositivity in $64 \%(16 / 25)$, but only using symptomatic animals from the city of Recife in the Brazilian state of Pernambuco (PE). In the same study, but in Paulista, also a city endemic for VL, Dantas-Torres and Brandão Filho [20] evaluated 322 dogs of which 130 (40.3\%) were found serologically positive by IFAT.

In the current study, 29 (90.6\%) of the 32 samples positive by IFAT were also positive by PCR for Leishmania spp. Out of the 18 negative samples, 11 (61.1\%) were equivalent to PCR. The IFAT sensitivity and specificity were $80.6 \%$ and $78.6 \%$, respectively (Table 2).

Although the Ministry of Health advocates euthanasia for ELISA-positive animals [9], in our study two dogs presented low titers (80), which could represent crossreaction with other pathogens phylogenetically similar to Leishmania spp., as observed in a work of Luciano et al. [18]. The other 30 animals presented higher levels, which usually indicates infection. However, both of them reacted positively to genus-specific PCR of blood cultures, suggesting that low titers are also related to the infection.

Only three samples of dogs from Campo Grande were negative by PCR and positive by IFAT. This difference found among the results of serological, parasitological and molecular methods may be attributable to such factors as the permanence of circulating antibodies in the peripheral blood even after parasite elimination, low quantity of circulating Leishmania spp. at the collection moment and consequently not detected by PCR. Yet some serology cross-reactions may be due to the existence of antigenic determinants and proteins common to parasites such as Trypanosoma cruzi $[18,21]$.

The Leishmania spp. infection in dogs from Campo Grande was minor by IFAT when compared to PCR, which presented $72.0 \%$ positivity. Seven dogs were nonreactive by IFAT, but positive by PCR. The immunodeficiency of some dogs or the existence of animals whose 
immune system can quell the infection and render the parasite inert in the organism may have contributed to these results. Lachaud et al. [22], comparing PCR to serology, obtained a $79.8 \%$ prevalence of canine infection through PCR versus $29.6 \%$ through serology and demonstrated that the antigens from kinetoplast were more sensitive, especially K13A-K13B and RV1-RV2, detecting $10^{-3}$ parasites per cubic millimeter of blood.

Leontides et al. [23] studied 73 healthy dogs from an endemic area in Greece, using IFAT and PCR in serum and bone marrow. The authors found $46(63 \%)$ positive samples by PCR, whereas only nine $(12.3 \%)$ by IFAT, clearly demonstrating that most dogs from this endemic area had been infected, but were still seronegative.

An important aspect that is probably associated with the nonsuccess of VL control is the selection of dogs for euthanasia by only serologic techniques whose low sensitivity and specificity result in underestimated infection rates (false negatives), thus enabling the maintenance of infected animals in endemic areas and consequently interfering in the impact that the elimination of dogs produces in the control of VL $[24,25]$.

It can be concluded that, by associating serological and molecular techniques, a greater number of infected animals can be detected and consequently eliminated, thus contributing to the control of the illness. On the other hand, many animals can be spared with a judicious analysis of their results by the employment of one more diagnostic test.

After the completion of the procedures for the evaluation of the detection threshold of Leishmania spp. DNA through PCR, it was verified through electrophoresis that bands with $720 \mathrm{bp}$ were present in the sample of pure culture, as well as at the $10^{3}, 10^{2}$ and $10^{1}$ dilutions. There was no detection of such a band at the $10^{\circ}$ dilution. Therefore, it is concluded that the analytic sensitivity of PCR, using the initiators LIN R4 and LIN19, was 10 parasites $/ \mathrm{mL}$.

In Campo Grande, out of 50 feline samples, 15 (30\%) were positive by IFAT, with titers varying from 40 to 320 . Similar positivity was found in a study by Martins et al. [26], who found, through the ELISA serologic method, $27.6 \%$ positivity in 112 samples of feline serum from the CZC of Araçatuba, SP, another city endemic for leishmaniasis. Da Silva et al. [3], using IFAT to assess eight samples of cat serum, obtained two samples positive (25\%) for VL, with titers of 40 and 320. In Spain, Martín-Sanchez et al. [27] found a seropositivity of $60 \%$ in an analysis of one 183 sera. And in a study conducted in Italy, Poli et al. [28] identified only one positive sample $(0.9 \%)$ out of one hundred and ten analyzed by IFAT.

The serology of infected cats is usually less specific than it is in dogs, because the production of antibodies against Leishmania spp. is smaller, which can render them seronegative [28]. Serological surveys performed through different techniques have shown that the prevalence of antibodies for Leishmania spp. in cats examined around the world varies from zero to $68.0 \%$. This sensitivity of feline seroprevalence can vary according to the methodology used (sampling, serological technique and adopted cutoff point) and the geographic region where the study is made.

The supposition that the Leishmania spp. infection, with or without clinical symptoms, is misdiagnosed in countries where the illness is endemic would account for the discrepancy between the high rates of infection obtained in epidemiological studies and the low number

Table 3 Statistical analysis for blood culture considering polymerase chain reaction (PCR) for Leishmania spp. as the gold standard

\begin{tabular}{|c|c|c|c|c|c|c|c|c|}
\hline Test & City & Species & $(\mathrm{nr} / \mathrm{np} / \mathrm{nt})^{(\mathrm{a})}$ & Sens $^{(b)}(\%)$ & $\operatorname{Spe}^{(\mathrm{c})}(\%)$ & $A c^{(d)}(\%)$ & Kappa ${ }^{(e)}$ & $p^{(f)}$ \\
\hline \multirow[t]{4}{*}{ BC } & Botucatu (SP) & Dog & $(3 / 0 / 50)$ & - & 94.0 & - & - & - \\
\hline & & Cat & $(2 / 0 / 50)$ & - & 96.0 & - & - & - \\
\hline & Campo Grande (MS) & Dog & $(29 / 36 / 50)$ & 69.4 & 71.4 & 70.0 & 0.35 & 0.009 \\
\hline & & Cat & $(0 / 0 / 50)$ & - & 100.0 & - & - & - \\
\hline \multirow[t]{4}{*}{ IFAT } & Botucatu (SP) & Dog & $(0 / 0 / 50)$ & - & 100.0 & - & - & - \\
\hline & & Cat & $(0 / 0 / 50)$ & - & 100.0 & - & - & - \\
\hline & Campo Grande (MS) & Dog & $(32 / 36 / 50)$ & 80.6 & 78.6 & 80.0 & 0.54 & $<0.01$ \\
\hline & & Cat & $(15 / 0 / 50)$ & - & 70.0 & - & - & - \\
\hline
\end{tabular}

$B C$ blood culture, IFAT immunofluorescent antibody test.

${ }^{\text {(a) }}$ nr: number of positive leishmaniasis diagnoses through BC or IFAT; np: number of positive diagnoses for Leishmania spp. through PCR exam; nt: total number of dogs.

${ }^{(b)}$ Sensitivity estimate (\% of true positives for leishmaniasis).

${ }^{\text {(c) }}$ Specificity estimate (\% of true negatives for leishmaniasis).

(d) Accuracy estimate (\% of correct diagnosis through hemoculture and IFAT).

${ }^{(e)}$ Kappa coefficient of concordance.

${ }^{(f)}$ Descriptive level associated with estimated kappa coefficient. 
of clinical cases described. Perhaps this low quantity of reported cases is due to a scarcity of serological surveys in endemic areas, difficulties in distinguishing between $\mathrm{FL}$ and other common feline diseases and the fact that many cases are diagnosed only when the animals become symptomatic [3].

In our study, only dogs coming from Mato Grosso do Sul state were positive for Leishmania spp. by PCR, by which $36(72 \%)$ of the 50 dogs evaluated were positive. Only four dogs $(11.1 \%)$ with positive PCR were asymptomatic. Thirty-two animals (88.9\%) were positive by PCR for Leishmania spp. and presented various clinical changes: 28 dogs (77.8\%) had weight loss; 22 dogs (61.1\%) had skin changes; 19 (52.8\%) had lymphadenopathy; 16 (44.4\%) had onychogryphosis; 12 (33.3\%) had alopecia, and 11 (30.5\%) had ocular lesions.

Fifty dog serum samples and 50 cat serum samples (Table 3) from Botucatu were 100\% negative by IFAT, the same results obtained by Langoni et al. [29], using the same diagnostic technique to test 781 sera of dogs in this locality. This study contributed to the active surveillance of leishmaniasis in the city, according to measures suggested by the Ministry of Health, whose new focus is to incorporate the "silent" states and cities, in other words, those with no reports of the disease in humans or dogs, by monitoring that aims to avoid or minimize the problems related to this affliction in areas without transmission [30].

\section{Conclusions}

In Campo Grande (MS), the IFAT technique for the diagnosis of Leishmania spp. in dogs demonstrated greater accuracy in relation to blood culture, whereas the PCR technique is considered the gold standard given its greater sensitivity and specificity. A higher number of these infected dogs were identified by means of PCR, thus improving and contributing to the identification of reservoir animals and, consequently, to the control of leishmaniasis.

The positivity of cats by IFAT in Campo Grande (MS) indicates their possible involvement in the leishmaniasis epidemiological cycle, which highlights the extreme importance of continuing the investigation of the disease in this species.

The positivity of blood culture observed in dogs and cats from Botucatu (SP) suggests the necessity of investigation for other parasites, such as Trypanosoma cruzi.

\section{Ethics committee approval}

The present study was approved by the Ethics Committee on Animal Experimentation of the School of Veterinary Medicine and Animal Husbandry, São Paulo State University (UNESP - Universidade Estadual Paulista), Botucatu, SP, Brazil under protocol number 65/2007.
Competing interests

The authors declare that there are no competing interests.

\section{Authors' contributions}

ARCB participated in the design of the study, carried out the blood collection from the dogs and cats, performed the diagnostic tests, the analysis of the results and article writing. SBL participated in the design of the study, the analysis of the results and the article writing. HL participated in the analysis of the results and the article writing. All authors read and approved the final manuscript.

\section{Acknowledgments}

The authors would like to thank the State of São Paulo Research Foundation (FAPESP) for financial support, the Center for Zoonosis Control in Campo Grande, MS, Brazil and the Municipal Kennel and Animal Protection Association (APA) in Botucatu, SP, Brazil, for their help with the experimental procedures.

\section{Author details}

${ }^{1}$ Mineiro Institute of Agriculture (IMA), Uberaba, Minas Gerais state, Brazil. ${ }^{2}$ Department of Veterinary Hygiene and Public Health, School of Veterinary Medicine and Animal Husbandry, São Paulo State University (UNESP - Univ Estadual Paulista), Botucatu, São Paulo State, Brazil. ${ }^{3}$ Agência Paulista de Tecnologia dos Agronegócios (APTA/SAA), Polo Regional Centro-Oeste, Av. Rodrigues Alves, 40-40, Bauru SP CEP 17030-000, Brazil.

Received: 23 October 2013 Accepted: 17 February 2014

Published: 24 February 2014

\section{References}

1. Kuhls K, Alam MZ, Cupolillo E, Ferreira GEM, Mauricio IL, Oddone R, Feliciangeli MD, Wirth T, Miles MA, Schonian G: Comparative microsatellite typing of new world Leishmania infantum reveals low heterogeneity among populations and its recent old world origin. PLoS Negl Trop Dis 2011, 5(6):e1155

2. Romero GA, Boelaert M: Control of visceral leishmaniasis in latin america - a systematic review. PLoS Neg/ Trop Dis 2010, 4(1):e584.

3. da Silva AVM, de Souza Cândido CD, Pita-Pereira D, Brazil RP, Carreira JCA: The first record of American visceral leishmaniasis in domestic cats from Rio de Janeiro, Brazil. Acta Trop 2008, 105(1):92-94.

4. Simões-Mattos L, Mattos MRF, Teixeira MJ, Oliveira-Lima JW, Bevilaqua CML, Prata-Júnior RC, Holanda CM, Rondon FCM, Bastos KMS, Coêlho ZCB, Coêlho ICB, Barral A, Pompeu MML: The susceptibility of domestic cats (Felis catus) to experimental infection with Leishmania braziliensis. Vet Parasitol 2005, 127(3-4):199-208.

5. Dantas-Torres F, Simões-Matos L, Brito FLC, Figueiredo LA, Faustino MAG: Leishmaniose Felina: revisão de literatura. Rev Clín Vet 2006, 61:32-40.

6. Quinnell RJ, Courtenay O: Transmission, reservoir hosts and control of zoonotic visceral leishmaniasis. Parasitology 2009, 136(14):1915-1934.

7. Maia C, Campino L: Can domestic cats be considered reservoir hosts of zoonotic leishmaniasis? Trends Parasitol 2011, 27(8):341-344.

8. Secretaria de Vigilância em Saúde: Departamento de Vigilância Epidemiológica: Manual de vigilância e controle da leishmaniose visceral. In Série A. Normas e manuais técnicos. Brasília: Ministério da Saúde. 2003:9-18.

9. Secretaria de Vigilância em Saúde: Departamento de Vigilância das Doenças Transmissíveis: Nota técnica conjunta N¹/2011 CGDT-CGLAB/ DEVIT/SVS/MS. In Esclarecimentos sobre substituição do protocolo diagnóstico da leishmaniose visceral canina (LVC). Brasília: Ministério da Saúde; 2011.

10. Greene CE: In Infectious diseases of the dog and cat. 3rd edition. Edited by Greene CE. Canadá: Saunders/Elsevier; 2006:1387.

11. Ikeda-Garcia FA, Marcondes M: Métodos de diagnóstico da leishmaniose visceral canina. Rev Clín Vet 2007, 71:34-42.

12. Pinto PLS: Circulação e caracterização de Trypanosoma cruzi isolados de mamíferos silvestres capturados no Estado de São Paulo, Brasil. Rev Inst Med Trop Sao Paulo 2001, 43(1):44.

13. Ikonomopoulos J, Kokotas S, Gazouli M, Zavras A, Stoitsiou M, Gorgoulis VG: Molecular diagnosis of leishmaniosis in dogs. Comparative application of traditional diagnostic methods and the proposed assay on clinical samples. Vet Parasitol 2003, 113(2):99-113. 
14. Camargo ME: Fluorescent antibody test for the sorodiagnosis of american tripanosomiasis: technical modification employing preserved culture forms of Trypanosoma cruzi in a slide test. Rev Inst Med Trop Sao Paulo 1966, 8(5):227-234.

15. Medronho AR, Bloch KV, Luiz RR, Werneck GL: Epidemiologia. $2^{\circ}$ edição. Atheneu: São Paulo; 2009.

16. Avelar JB: Caracterização molecular de isolados de Trypanosoma cruzi obtidos de mulheres durante a fase crônica da doença de Chagas. In Dissertação de Mestrado. Universidade Federal de Goiás, Instituto de Patologia Tropical e Saúde Pública; 2008. Available at: http://www.openthesis. org/documents/molecular-de-isolados-Trypanosoma-cruziobtidos-287795.html.

17. Chiari E: Chagas disease diagnosis using polymerase chain reaction, hemoculture and serologic methods. Mem Inst Oswaldo Cruz 1999, 94(Suppl 1):299-300

18. Luciano RM, Lucheis SB, Troncarelli MZ, Luciano DM, Langoni H: Avaliação da reatividade cruzada entre antígenos de Leishmania spp. e Trypanosoma cruzi na resposta sorológica de cães pela técnica de imunofluorescência indireta (RIFI). Braz J Vet Res Anim Sci 2009, 46(3):181-187

19. Albuquerque AR, Aragão FR, Faustino MAG, Gomes YM, Lira RA, Nakasawa M, Alves LC: Aspectos clínicos de cães naturalmente infectados por Leishmania (Leishmania) chagasi na região metropolitana do Recife. Rev Clín Vet 2007, 71:78-80.

20. Torres FD, Brandão Filho SP: Soroprevalência da leishmaniose visceral canina no Município de Paulista, Pernambuco, Brasil. In Anclivepa Brasil. 3rd edition. 2005:343-344. http://www.uece.br/cienciaanimal/dmdocuments/ Comunicacao1.2006.1.pdf.

21. Troncarelli MZ, Camargo JB, Machado JG, Lucheis SB, Langoni H Leishmania spp. and/or Trypanosoma cruzi in dogs from endemic and nonendemic areas for canine visceral leishmaniasis. Vet Parasitol 2009, 164(2-4):118-123.

22. Lachaud L, Machergui-Hammami S, Chabbert E, Dereure J, Dedet JP, Bastien P: Comparison of six PCR methods using peripheral flood for detection of canine visceral leishmaniasis. J Clin Microbiol 2002, 40(1):210-215.

23. Leontides $L S$, Saridomichelakis MN, Billinis C, Kontos V, Koutinas AF, Galatos AD, Mylonakis ME: A cross-sectional study of Leishmania spp. infection in clinically healthy dogs with polymerase chain reaction and sorology in Greece. Vet Parasitol 2002, 109(1-2):19-27.

24. Silva AVM, Paula AA, Cabrera MAA, Carreira JCA: Leishmaniose em cães domésticos: aspectos epidemiológicos. Cad Saude Publ 2005, 21(1):324-328.

25. Andrade HM, Reis AB, dos Santos SL, Volpini AC, Marques MJ, Romanha AJ: Use of PCR-RFLP to identify Leishmania species in naturally-infected dogs. Vet Parasitol 2006, 140(3-4):231-238

26. Martins CO, Rossi CN, Marcondes M, Neto LS, Lima VMF: Detecção de anticorpos anti-Leishmania spp. em Felis catus na área endêmica de Araçatuba, São Paulo, Brasil. Vet Zootec 2008, 15(2):56.

27. Martín-Sanchez J, Acedo C, Muñoz-Pérez M, Pesson B, Marchal O, MorillasMárquez F: Infection by Leishmania infantum in cats: epidemiological study in Spain. Vet Parasitol 2007, 145(3-4):267-273.

28. Poli A, Abramo F, Barsotti P, Leva S, Gramiccia M, Ludovisi A, Mancianti F: Feline leishmaniosis due to Leishmania infantum in Italy. Vet Parasitol 2002, 106(3):181-191.

29. Langoni H, Modolo JR, Souza LC, Araujo WN, Shimabukuro FH, Mendonça AO, Leite BLS, Padovani CR: Epidemiological vigilance for canine leishmaniasis in the county of Botucatu, SP, Brazil. ARS Vet 2001, 17(3):196-200

30. Ministério da Saúde, Brasil, Secretaria de Vigilância em Saúde. Departamento de Vigilância Epidemiológica: Manual de vigilância e controle da leishmaniose visceral / Ministério da Saúde, Secretaria de Vigilância em Saúde, Departamento de Vigilância Epidemiológica. Brasília: Editora do Ministério da Saúde: il. color - (Série A. Normas e Manuais Técnicos); 2006:120p.

doi:10.1186/1678-9199-20-5

Cite this article as: Braga et al:: Evaluation of canine and feline leishmaniasis by the association of blood culture, immunofluorescent antibody test and polymerase chain reaction. Journal of Venomous Animals and Toxins including Tropical Diseases 2014 20:5.

\section{Submit your next manuscript to BioMed Central and take full advantage of:}

- Convenient online submission

- Thorough peer review

- No space constraints or color figure charges

- Immediate publication on acceptance

- Inclusion in PubMed, CAS, Scopus and Google Scholar

- Research which is freely available for redistribution

Submit your manuscript at www.biomedcentral.com/submit
Biomed Central 